\title{
Validity and reliability testing of a short questionnaire developed to assess consumers' use, understanding and perception of food labels
}

\author{
D. Mackison ${ }^{1}$, A. S. Anderson ${ }^{1}$ and W. L. Wrieden ${ }^{2}$ \\ ${ }^{1}$ Centre for Public Health Nutrition Research, University of Dundee, Dundee DD1 9SY, UK and ${ }^{2}$ Health Services \\ Research Unit, University of Aberdeen, Aberdeen AB25 2ZD, UK
}

Food labels play a critical role in communicating nutrition information to the consumer. Given their potential to influence dietary choice, it is imperative to understand the consumers' use and comprehension of food labels if the presentation of nutrition information is to become both mandatory and standardized in the $\mathrm{EU}^{(1)}$. The present study aims to assess the validity and reliability of a short (self-complete) questionnaire designed to assess consumers' use and understanding of food labels.

The questionnaire content was determined by gaps highlighted in a recent literature review of food labelling ${ }^{(2)}$. Nineteen questions (fortynine items) assessing frequency of label reading, perceived importance of food labels, regularity of dining out, desire to have nutrition information at specific catering outlets and ability to perform nutrition information tasks were formulated and presented on four pages of A4. With the exception of two open questions, all items were presented as closed (field box) structures and in accordance with best practice guidelines $^{(3)}$. Content validity, face validity, item analysis, repeat reliability and internal reliability were assessed.

Nutrition experts (n 26) completed detailed content validity assessments, resulting in high scores for appropriateness, importance and phrasing of questions, although grammar and terminology changes were required. Face validity indicated the questionnaire was quick to complete ( $<15 \mathrm{~min}$ ), easy to follow and comprehensible. Cronbach's alpha scores ${ }^{(4)}$ (internal reliability) for questions with multiple sections ranged from 0.72 to 0.91 , indicating good internal consistency. Repeat reliability testing showed Spearman correlation coefficients ranging from 0.51 to 0.97 (all $P<0.001$ ) indicating high temporal stability. Both item difficulty ${ }^{(5)}$ and item discrimination analysis ${ }^{(6)}$ indicated questions were at an appropriate level (Table).

\begin{tabular}{lcc}
\hline $\begin{array}{l}\text { Questions objectively assessing } \\
\text { ability to perform nutrition label tasks }\end{array}$ & $\begin{array}{c}\text { Difficulty } \\
\text { answering correctly) }\end{array}$ & $\begin{array}{c}\text { Discrimination } \\
\text { (item-total r value) }\end{array}$ \\
\hline Sugar content in two servings & 51.4 & 0.57 \\
Grams of fat in half pack & 61.4 & 0.64 \\
Servings in pack & 71.4 & 0.55 \\
Fat content in product 1 & 60.0 & 0.43 \\
Fat content in product 2 & 38.6 & 0.53 \\
Sugar content in product 3 & 62.9 & 0.47 \\
Comparing the fat content of 2 products & 67.1 & 0.70 \\
Judging fat content after comparison & 28.6 & 0.50 \\
Losing weight & 72.9 & 0.63 \\
Salt intake & 71.4 & 0.63 \\
\hline
\end{tabular}

In conclusion, this questionnaire is a suitable tool for assessing consumers' use, understanding and perception of food labels.

This work was funded by the Food Standards Agency Postgraduate Scholarship Scheme.

1. European Commission (2008) Proposal for a regulation of the European Parliament and of the Council on the provision of food information to consumers. http://ec.europa.eu/food/food/labellingnutrition/foodlabelling/proposed_legislation_en.htm

2. Mackison D, Anderson AS \& Wrieden WL (2008) Proc Nutr Soc 67, E215.

3. Edwards PJ, Roberts IG, Clarke MJ et al. (2008) Methods to increase response rates to postal questionnaires. http://mrw.interscience.wiley.com/ cochrane/clsysrev/articles/MR000008/frame.html

4. Bland MJ \& Altman DG (1997) Br Med J 314, 572.

5. Kline P (1993) The Handbook of Psychological Testing. London: Routledge.

6. Kline P (1986) A Handbook of Test Construction. Introduction to Psychometric Design. London: Methuen \& Co Ltd. 